\title{
Dyrithiopsis lakefuxianensis gen. et sp. nov. from Fuxian Lake, Yunnan, China, and notes on the taxonomic confusion surrounding Dyrithium
}

\section{R. Jeewon ${ }^{1}$}

School of Biological Sciences, King Henry Building, University of Portsmouth, Portsmouth, PO1 2DY, United Kingdom

L. Cai

Centre for Research in Fungal Diversity, Department of Ecology E B Biodiversity, University of Hong Kong, Pokfulam Road, Hong Kong, SAR, PR China

E. C. Y. Liew

School of Land, Water $\mathcal{E}$ Crop Sciences, McMillan Building A05, University of Sydney, NSW 2006, Australia

K. Q. Zhang

Laboratory for conservation and Utilization of Bioresource, Yunnan University, Kunming, Yunnan, PR China

K. D. Hyde

Centre for Research in Fungal Diversity, Department of Ecology Ẽ Biodiversity, University of Hong Kong, Pokfulam Road, Hong Kong, SAR, PR China

Abstract: A new taxon with Dyrithium-like characteristics was collected from Lake Fuxian in China. The taxon is typical of the Amphisphaeriaceae in that it has relatively large, ostiolate, immersed ascomata, unitunicate asci with a $\mathrm{J}+$ subapical ring, and brown ascospores. It is similar to Dyrithium in that it has muriform ascospores, but considerable confusion surrounds this genus. In Dyrithium asci are bitunicate and lack a J+ subapical ring, while this was not true of our species. A new genus, Dyrithiopsis, therefore is established to accommodate this new taxon. Details of its anamorph also are provided, based on cultural studies. Parsimony analyses of part of the large-subunit rDNA provide further evidence to support the familial placement of this new genus in the Amphisphaeriaceae. The taxonomic position of Dyrithium also is discussed.

Key words: Amphisphaeriaceae, anamorph, Pestalotiopsis, phylogeny, rDNA

Accepted for publication March 13, 2003.

${ }^{1}$ Corresponding author. E-mail: rjeewon@graduate.hku.hk

\section{INTRODUCTION}

Dyrithium M.E. Barr is a monotypic genus represented by Sphaeria livida Fr., which was included in the Amphisphaeriaceae by Barr (1994). However, Kang et al (1999a) re-examined genera in the Amphisphaeriaceae and excluded Dyrithium because the asci in the collection they examined were bitunicate. This collection had been listed as a collection of Dyrithium lividum (Fr.) M.E. Barr by Barr (1994). However, Kang et al (1999a) had not examined the holotype of Sphaeria livida.

During a biodiversity survey of fungi on submerged wood in Lake Fuxian, Yunnan, China (Cai et al 2002), we collected a taxon with characteristics that keyed out to Dyrithium in the key provided by Barr (1994). Ascospores were brown and muriform, while asci were unitunicate and the ostiolate ascomata were relatively large and immersed. The taxon differed from Dyrithium, however, in that it clearly has unitunicate asci with a $\mathrm{J}+$ subapical ring. In this respect it was even more typical of the Amphisphaeriaceae.

The objectives of this study are: (i) to establish $D y$ rithiopsis as a new genus: (ii) to support its inclusion in the family Amphisphaeriaceae based on phylogenetic analyses of part of the rDNA sequences; and (iii) to discuss its morphological affinities with Dyrithium.

\section{MATERIALS AND METHODS}

Morphological and cultural studies.-A fresh specimen of the new species collected from Yunnan, China, and the herbarium specimen of Dyrithium obtained from UPS were examined morphologically. To establish anamorph-teleomorph connections of the new species, single ascospores from ascomata were isolated by micromanipulation, following the procedures as outlined by Goh (1999) and Choi et al (1999), and allowed to grow on PDA agar under light at 24-26 C. For examination of morphological features of the teleomorph, cotton blue/lactic acid and phase-contrast microscopy were used. Measurements of the conidia arising from the single ascospore culture were done in water.

DNA extraction, amplification and sequencing.-Single-spore cultures of the new species were grown on PDA medium for $3 \mathrm{wk}$. Sources, Genbank accession numbers, designation and geographical origin of species used in this study are listed in TABLE I. Mycelia were used as the starting material for DNA extraction, following a modified protocol of Doyle 
TABLE I. Fungal strains used in the study, and their accession numbers, hosts and locality

\begin{tabular}{|c|c|c|c|}
\hline Species & $\begin{array}{l}\text { Source of } \\
\text { cultures }^{\mathrm{a}}\end{array}$ & Host, geographic origin & GenBank No. \\
\hline \multicolumn{4}{|l|}{ Ingroup } \\
\hline Amphisphaeria umbrina & HKUCC 994 & Tilia sp., Switzerland & AF452029 \\
\hline Bartalinia robillardoides & BRIP 14180 & Macrotyloma daltonii, Australia & AF382366 \\
\hline Discosia sp. & HKUCC 6626 & Unidentified dead leaf, Hong Kong & AF382381 \\
\hline Discostroma tosta & HKUCC 1004 & Unidentified terrestrial wood, Hong Kong & AF382380 \\
\hline Dyrithiopsis lakefuxianensis & HKUCC 7303 & Submerged wood, China & AF452047 \\
\hline Lepteutypa cupressi & IMI 052255 & Cupressus forbesii, Kenya & AF382379 \\
\hline Monochaetia monochaeta & CBS 199.82 & Quercus pubescens, Italy & AF382370 \\
\hline Pestalotia palmarum & ATCG 10085 & Coconut Palm, India & AF382361 \\
\hline Pestalotia vaccinii & ICMP 5446 & Vaccinium sp., New Zealand & AF382362 \\
\hline Pestalotiopsis maculans & CBS 322.76 & Camellia sp., France & AF382354 \\
\hline Pestalotiopsis versicolor & BRIP 14534 & Psidium guajava, Australia & AF382357 \\
\hline Seimatosporium vaccinii & ICMP 7003 & Vaccinium ashei Reade, New Zealand & AF382374 \\
\hline Seiridium cupressi & FABI, CMW 5596 & Cupressus sempervirens, S. Africa & AF382378 \\
\hline Truncatella angustata & ICMP 7062 & Malus domestica, New Zealand & AF382383 \\
\hline \multicolumn{4}{|l|}{ Outgroups } \\
\hline Diaporthe phaseolorum & $\mathrm{NA}^{\mathrm{b}}$ & $\mathrm{NA}^{\mathrm{b}}$ & $\mathrm{U} 47830$ \\
\hline Dothidea sambuci & CBS 198.58 & Acer pseudoplatanus, Switzerland & AF382387 \\
\hline Hypocrea schweinitzii & & $\mathrm{NA}^{\mathrm{b}}$ & U47833 \\
\hline Ophiostoma africanum & $\mathrm{NA}^{\mathrm{b}}$ & $\mathrm{NA}^{\mathrm{b}}$ & AF221015 \\
\hline Nectria pityrodes & ATCC 208843 & $\mathrm{NA}^{\mathrm{b}}$ & AF193240 \\
\hline Nectria sesquicili & ATCC 66880 & $\mathrm{NA}^{\mathrm{b}}$ & AF193241 \\
\hline Xylaria curta & $\mathrm{NA}^{\mathrm{b}}$ & $N^{b}$ & U47940 \\
\hline Xylaria hypoxylon ${ }^{c}$ & ATCC 42768 & $\mathrm{NA}^{\mathrm{b}}$ & $\mathrm{U} 47841$ \\
\hline
\end{tabular}

a ATCC: American Type Culture Collection; BRIP: Queensland Department of Primary Industries Plant Pathology Herbarium; CBS: Centraalbureau voor Schimmelcultures; FABI: Forestry and Agricultural Biotechnology Institute; HKUCC: The University of Hong Kong Culture Collection; ICMP: International Collection of Microorganisms from Plants.

${ }^{\mathrm{b}} \mathrm{NA}$ : Information not available.

and Doyle (1987). Part of the LSU of the rDNA was amplified by PCR with primers LROR and LR05. Amplified products then were purified using minicolumns, purification resin and buffer, according to the manufacturer's protocol (Wizard PCR Preps DNA Purification System). Purified products were sequenced directly, using primers LROR, LR3R, LR5, LR3 and other reagents, following the manufacturer's protocol (Pharmacia Biotech). Sequences were edited manually and assembled using the Alf software and SeqPup (Gilbert 1996).

Phylogenetic analyses.-Phylogenetic analyses were performed in PAUP* 4.0b9 (Swofford 2002) on part of the LSU of the rDNA sequenced. Analyses included representatives of members from other orders (sequences available from GenBank) to resolve phylogenetic relationships and to root cladograms. Trees were inferred using the heuristic search option with 10, 100 and 1000 random-sequence additions. Gaps were treated as missing data, and characters were unordered and weighted equally and differentially. Clade stability was assessed in a bootstrap analysis with 1000 replicates, random-sequence additions with maxtrees set to 5000 and other default parameters as implemented in PAUP*. For maximum-likelihood (ML) analyses, a single tree generated under the maximum-parsimony criterion was used as a starting tree and transition-transversion ratios, base frequencies and shape parameter were estimated. Using these initial estimates of substitution rates and kinds, a heuristic search with TBR branch swapping was used to find a maximum-likelihood tree. The gamma model of site-rate variation was used with no enforcement of a molecular clock. Initial branch lengths were obtained with Rogers-Swofford approximation methods. Neighbor-joining (NJ) analyses was conducted under different models of distance algorithms, including HKY85, JC, K2P and F81, and the support for individual clades within the tree was assessed by 1000 replicates of bootstrapping. Dothidea sambuci was used as outgroup.

\section{RESULTS}

\section{Description of Dyrithiopsis lakefuxianensis (teleo- morph)}

Dyrithiopsis L. Cai, R. Jeewon et K.D. Hyde, gen. nov.

[Ascomata immersa vel semi-immersa, subglobosa, nigra, coriacea, papillata, ostiolata, periphysata, paraphysata. Asci unitunicati, 8-spori, cylindrici, pedicellati, apparatus apicale $\mathrm{J}+$ praediti. Ascosporae, fusiformes vel ellipsoid, pallid brunneae, muriformes, euseptatae.] 


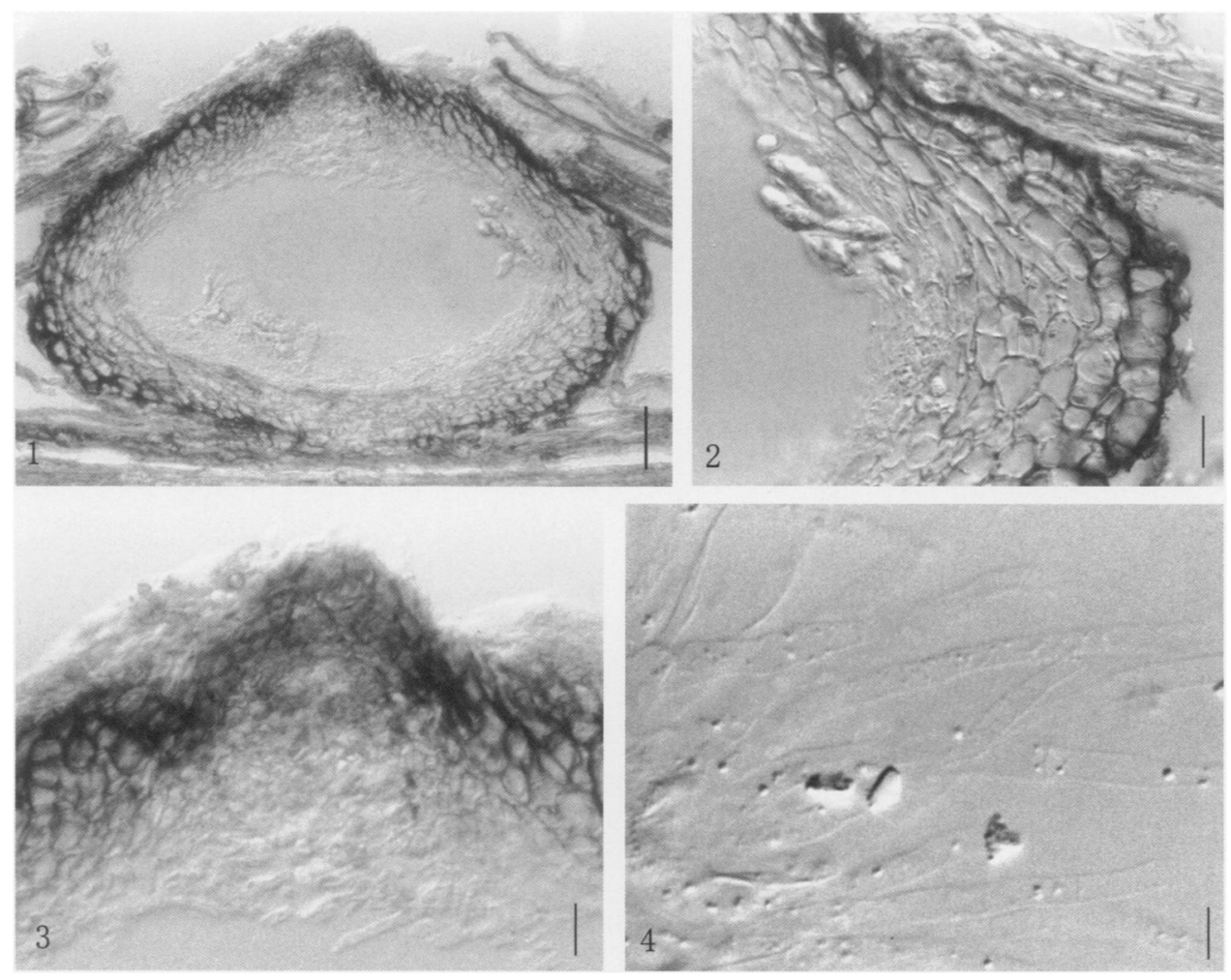

FIGS. 1-4. Interference contrast micrographs of Dyrithiopsis lakefuxianensis (from holotype HKU(M) 8280). 1. Section of the ascoma. 2-3. Section of the peridium. 4. Paraphyses. Scale bars: $1=50 \mu \mathrm{m}, 2-4=15 \mu \mathrm{m}$.

Ascomata immersed or semi-immersed, subglobose, blackened, coriaceous, papillate, ostiole, periphysate. Peridium dark brown. Paraphyses hypha-like, sparse, septate, tapering towards the ends. Asci unitunicate, 8-spored, cylindrical, pedicellate, apically rounded, discoid, $\mathrm{J}+$, subapical ring. Ascospores fusiform or ellipsoid, light brown, muriform, smoothwalled and euseptate.

Type species. Dyrithiopsis lakefuxianensis L. Cai, R. Jeewon and K.D. Hyde, sp. nov.

\section{Dyrithiopsis lakefuxianensis L. Cai, R. Jeewon et K.D.}

Hyde, sp. nov.

Figs. 1-12

Ascomata 250-370 $\mu \mathrm{m}$ diam, immersa vel semi-immersa, subglobosa, nigra, coriacea, gregaria, papillata, periphysata, paraphysata. Peridium 32-72 $\mu \mathrm{m}$ crassum, textura angulari (Figs. 2-3). Paraphyses ca $6 \mu \mathrm{m}$ crass, hyphoideus, sparsus, septatae (FIG. 4). Asci 87.5-125 × 11-14 $\mu \mathrm{m}$, 8-spori, cylindrici, unitunicati, pedicellati, apparatus apicale $\mathrm{J}+, 3-4.5$ $\mu \mathrm{m}$ diametro, 1.75-3 $\mu \mathrm{m}$ alto praediti. Ascosporae 15-22.5 $\times 7.5-10 \mu \mathrm{m}$, ellipsoid-fusiformes, pallide brunneae, muriformes.

Etymology. in reference to the collection site.

Ascomata 250-370 $\mu \mathrm{m}$ diam, immersed, becoming semi-immersed, subglobose, black, coriaceous, clustered in groups, papillate, ostiole periphysate (FIG. 1). Peridium 32-72 $\mu \mathrm{m}$ wide, comprising textura angularis, with light, brown walls inwardly and black- ened walls at the outside (FIGs. 2-3). Paraphyses up to $6 \mu \mathrm{m}$ wide at the base, hypha-like, sparse, septate, tapering toward the ends, shorter than asci (FIG. 4). Asci $87.5-125 \times 11-14 \mu \mathrm{m}(\bar{x}=107 \times 12.5 \mu \mathrm{m}, \mathrm{n}$ $=10$ ), 8-spored, cylindrical, unitunicate, pedicellate, apically rounded, with a discoid, $\mathrm{J}+$ subapical ring, 3-4.5 $\mu \mathrm{m}$ diam 1.75-3 $\mu \mathrm{m}$ high (Figs. 5-8). Ascospores $15-22.5 \times 7.5-10 \mu \mathrm{m}(\bar{x}=18.2 \times 8.6 \mu \mathrm{m}, \mathrm{n}$ $=25$ ), overlapping uniseriate, ellipsoid-fusiform, light brown, with 3 transverse septa and (0-) 1-2 longitudinal septa, smooth-walled (FIGs. 9-12).

Colonies on PDA growing quickly, up to $3 \mathrm{~cm}$ diam in $7 \mathrm{~d}$ at room temperature $(\sim 25 \mathrm{C})$, compact, white from above, woolly, lacking aerial mycelium, pale orange-brown from below, hyphae up to $6.5 \mu \mathrm{m}$ wide, septate, branched and smooth-walled, producing anamorph in culture (HKUCC 7303).

\footnotetext{
Description of Monochaetiopsis lakefuxianensis (anamorph)

Monochaetiopsis L. Cai, R. Jeewon et K.D. Hyde, gen. nov.

[Conidiomata nigra, coriacea, subglobosa, glabra, semiimmersa vel superficialia, disseminata vel gregaria; stroma basalis et textura angularis, cellae crassitunica, incolorii, conidiophori ex cellulis in cavitas de conidioma, enatus de superior cellae de stroma. Cellulae conidiogenae incolorii,
} 


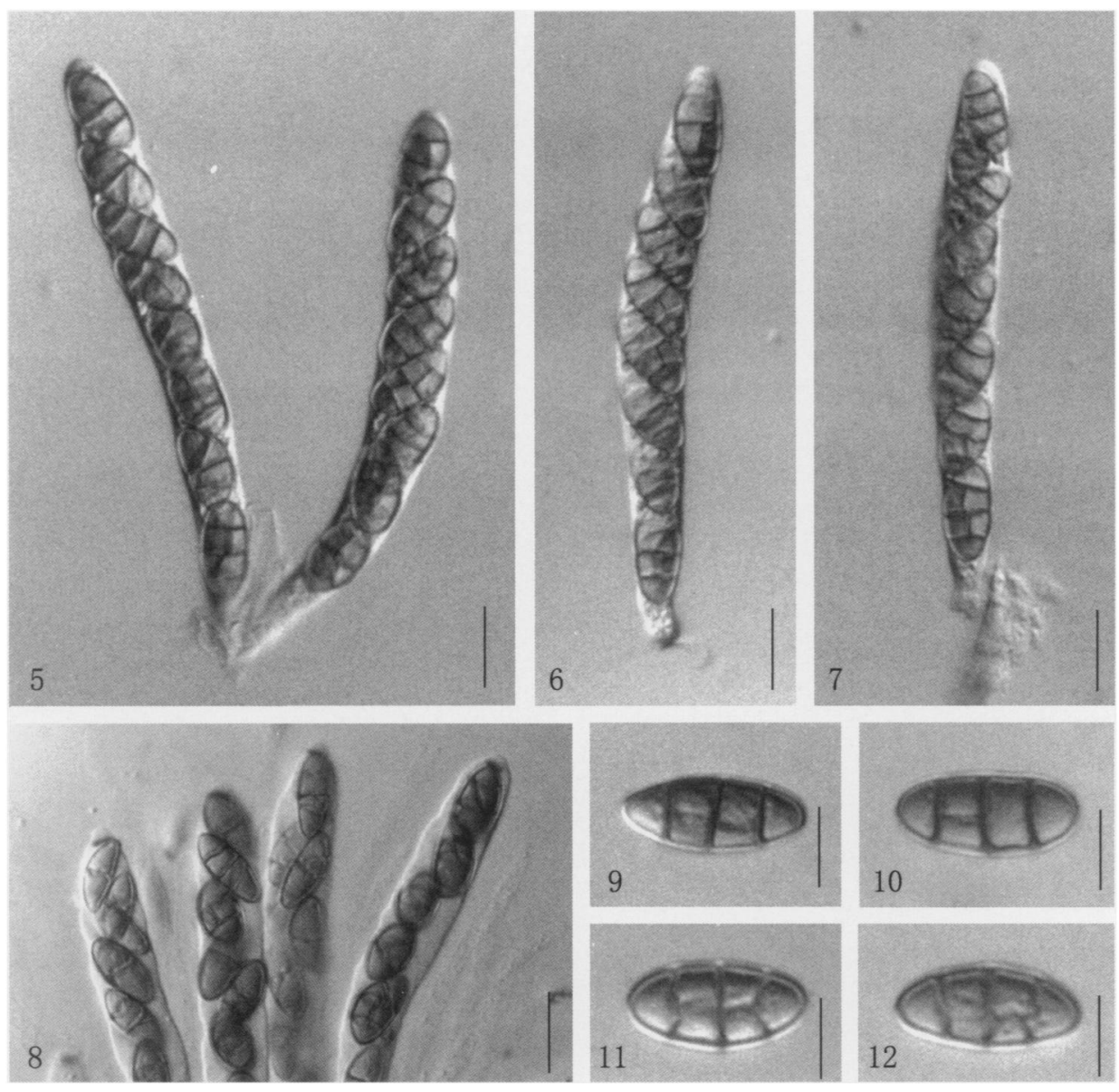

FiGs. 5-12. Interference contrast micrographs of Dyrithiopsis lakefuxianensis (from holotype). 5-8. Asci. Note J+ amyloid subapical ring. 9-12. Ascospores (muriform). Scale bars: 5-8 = $20 \mu \mathrm{m}, 9-12=10 \mu \mathrm{m}$.

laevis. Conidii fusiformie elliptica, directa vel arcuata, euseptatae, iferus appendicis; cella basalaris cum angustus truncatus basis, laevis, hyalina, 3-4 medius cellae pigmentum, pallida bruneus, breve cylindrica, concolor, septum parce colligo ad septa, appendicis tubularie, centralis, attenuare, directa, cellularie, non paniculata, solitaria, appendicis basalaris fere absens, cum praesens, solitaria, non paniculata, centralis, formata post deniceps de conidii.]

Conidiomata black, coriaceous, subglobose, glabrous, semi-immersed or superficial, scattered or gregarious; basal stroma textura angularis, cells thickwalled, colorless, conidiophores lining the cavity of the conidioma, arising from the upper cells of the basal stroma and reduced to conidiogenous cells. Conidiogenous cells integrated, colorless, smooth. Conidia fusiform elliptical, straight or curved, euseptate, bearing appendages; basal cell with a narrowly truncate base, smooth, hyaline, 3-4 median cells pale brown, short-cylindrical, concolorous, slightly constricted at the septa, with appendages tubular, centric, attenuated, straight, cellular, unbranched, single, basal appendages usually absent, when present, single, unbranched, centric, formed after secession of the conidia.

Type species. Monochaetiopsis lakefuxianensis L. Cai, R. Jeewon et K.D. Hyde, sp. nov.

Monochaetiopsis lakefuxianensis L. Cai, R. Jeewon et K.D. Hyde, sp. nov. FIGS. 13-20.

[Conidiomata 190-290 $\mu \mathrm{m}$ diam, nigra, coriacea, subglobosa, glabra, semiimmersa vel superficialia, disseminata vel gregaria; stroma basalis ad per $25 \mu \mathrm{m}$ crassum et textura angularis, cellae crassitunica, incolorii (FrG. 13), conidiophori ex cellulis in cavitas de conidioma, enatus de superior cellae de stroma. Cellulae conidiogenae integratae, incolorii, laevae (FIGS. 14-15). Conidii 29-40 $\times$ 5-7.5 $\mu \mathrm{m})$, fusiformes vel ellipsoideae, recta vel curvatea, euseptatae, fere 4 euseptata, raro 5 euseptata, iferus appendicis; cella basalaris cum angustus truncatus basis, laevis, hyalina, 3.8-7.5 $\mu \mathrm{m}$, longum, 3-4 medius cellae (pigmentum) pallida bruneus, breve cylindrica, concolor, septum leniter constricto ad septa, 21-29 $\mu \mathrm{m}$ longum; cellulae apicalis conicus hyalinae, laevae, 2.5-4.5 $\mu \mathrm{m}$ longum; apicalis appendices tubularie centralis, attenuare, recta, cellularie, non paniculata, singulis, 5-11 $\mu \mathrm{m}$ longum, appendicis basalaris fere 


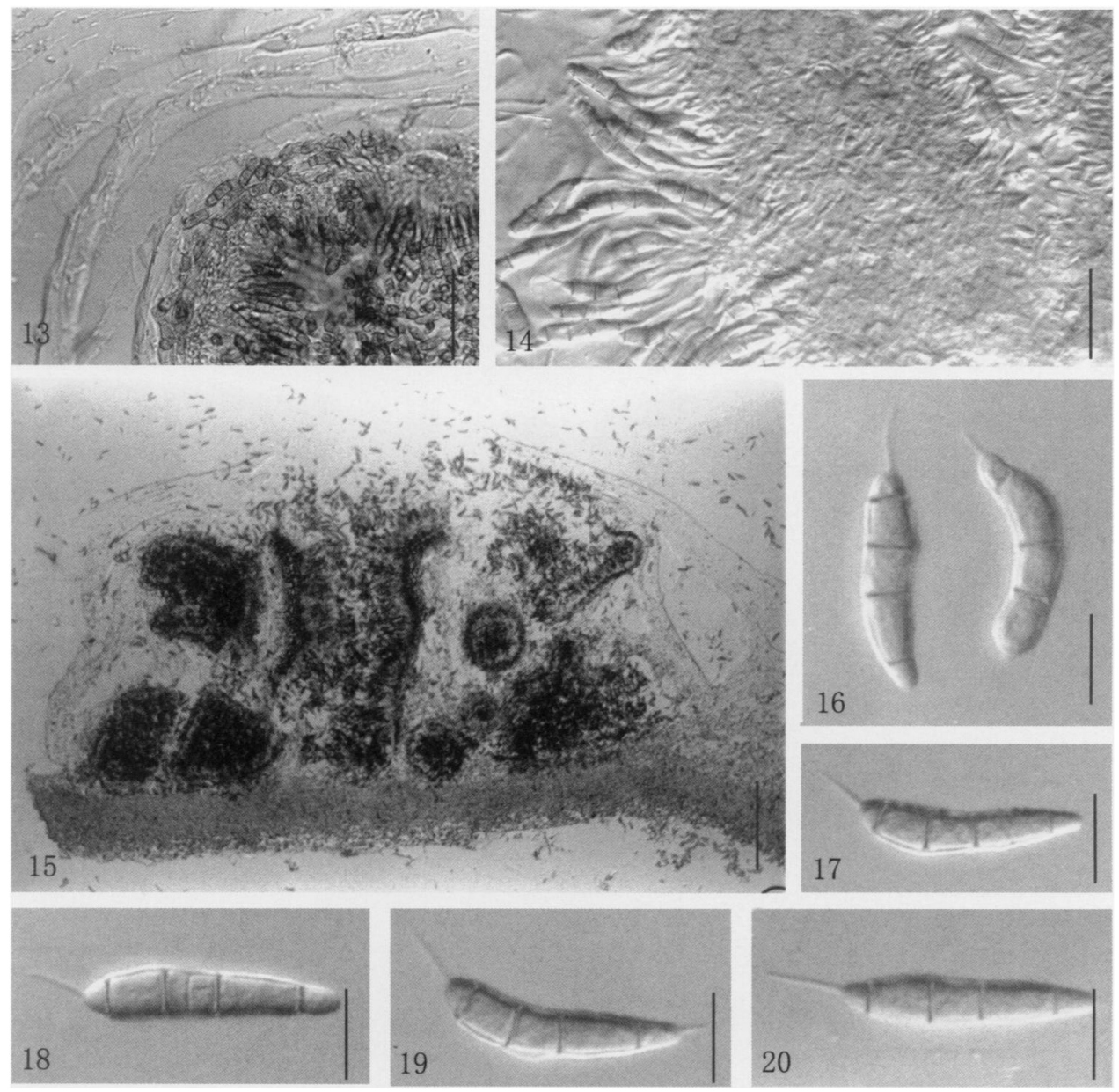

FIGS. 13-20. Interference contrast micrographs of Monochaetiopsis lakefuxianensis (from HKUCC holotype 7303 ). 13. Squash mount of conidioma and conidiophore. 14. Conidiogenous cells. 15. Section of the conidioma. 16-20.Conidia 4euseptate bearing short apical and basal appendages). Scale bars: $13=60 \mu \mathrm{m}, 14=30 \mu \mathrm{m}, 15=180 \mu \mathrm{m} 16-20=15 \mu \mathrm{m}$.

absens, cum praesens, singulis, non paniculata, centralis,, 4-22 $\mu \mathrm{m}$, formata post deniceps de conidii (FIGs. 16-20).J

Conidiomata 190-290 $\mu \mathrm{m}$ diam, black, coriaceous, subglobose, glabrous, semi-immersed or superficial, scattered or gregarious; basal stroma up to $25 \mu \mathrm{m}$ thick, of textura angularis, cells thick-walled, colorless (FIG. 13), conidiophores lining the cavity of the conidioma, arising from the upper cells of the basal stroma and reduced to conidiogenous cells. Conidiogenous cells integrated, colorless, smooth (FIGS. 14-15). Conidia 29-40 $\times$ 5-7.5 $\mu \mathrm{m}(\bar{x}=34 \times 6.3 \mu \mathrm{m}, \mathrm{n}=$ 20), fusiform elliptical, straight or curved, mostly 4 septate, occasionally 5-septate, bearing appendages; basal cell with a narrowly truncate base, smooth, hyaline, 3.8-7.5 $\mu \mathrm{m}(\bar{x}=5.1 \mu \mathrm{m}, \mathrm{n}=20)$ long; $3-4$ median cells (pigmented) pale brown, short-cylindrical, concolorous, slightly constricted at the septa, together with 21-29 $\mu \mathrm{m}(\bar{x}=25.6 \mu \mathrm{m}, \mathrm{n}=20)$ long, apical cell conical, colorless, smooth, 2.5-4.5 $\mu \mathrm{m}(\bar{x}$ $=3.5 \mu \mathrm{m}, \mathrm{n}=20$ ) long, apical appendages tubular, centric, attenuated, straight, cellular, unbranched, single, 5-11 $\mu \mathrm{m}(\bar{x}=8.8 \mu \mathrm{m}, \mathrm{n}=20)$ long, basal appendage usually absent, when present, single, unbranched, centric, 4-22 $\mu \mathrm{m}(\bar{x}=11 \mu \mathrm{m}, \mathrm{n}=6)$ formed after secession of the conidia (FIGS. 16-20).

Etymology. From Lake Fuxian (relating to the lake where it was collected).

Known habitat. On submerged wood in a lake in China.

Material examined. CHINA. Yunnan Province: Cheng Jiang, Fuxian Lake, on submerged twig, 28 Aug 2000, L. Cai, R. Jeewon and K.D. Hyde (HKU(M) 8280, [holotype, isotype in living culture HKUCC $7303]$.

Dyrithium lividum (Fr.) M.E. Barr, Mycotaxon 51:204 (1994). FIGs. 21-31. [ $\equiv$ Sphaeria livida (Fr.) Syst. Mycol. 2:479 (1823).]

Ascomata 570-680 $\mu \mathrm{m}$ wide, 460-540 $\mu \mathrm{m}$ high, immersed under a clypeus, visible as raised darkened oval regions on the host surface, subglobose to ellipsoidal, papillate, ostiole periphysate $70 \mu \mathrm{m}$ in diam 

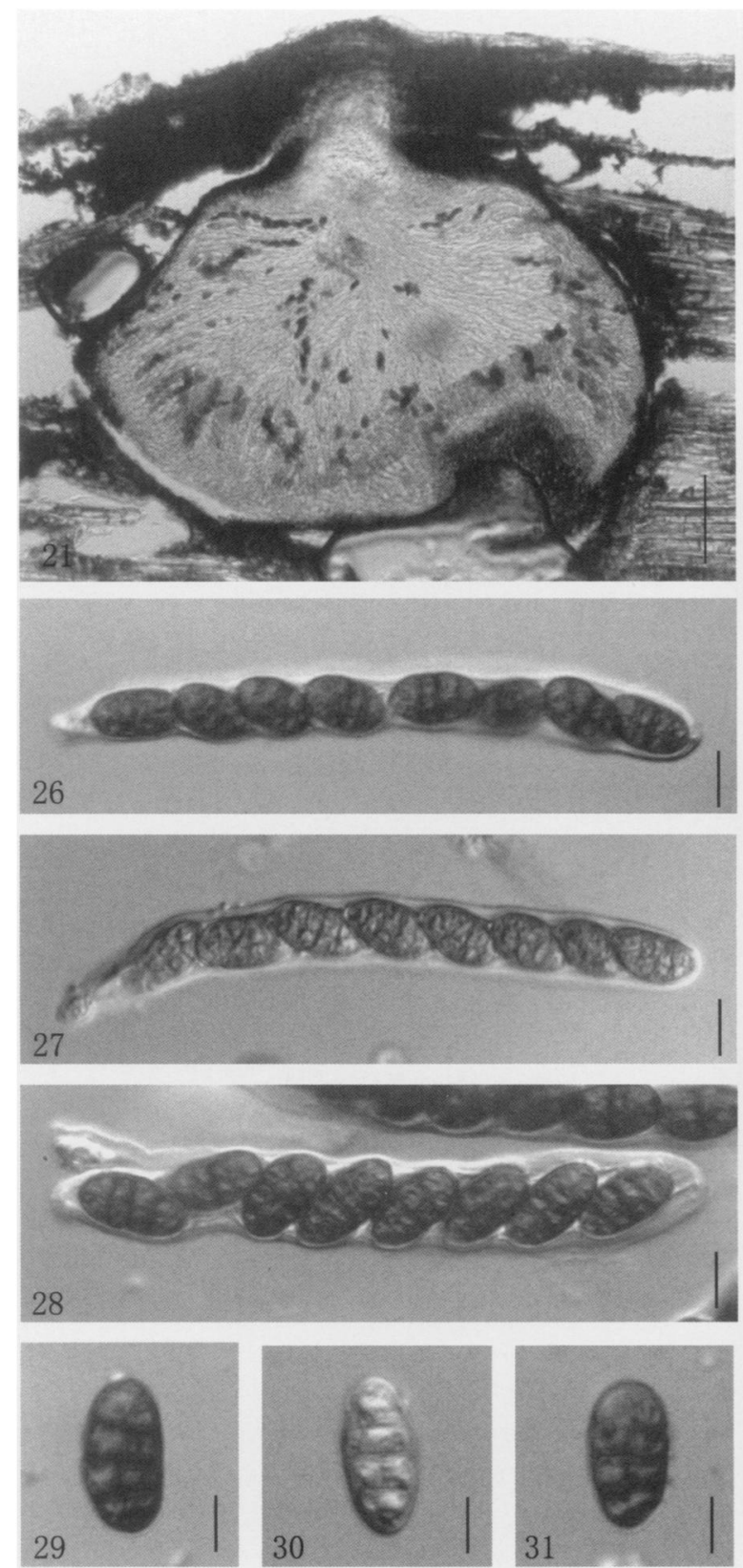
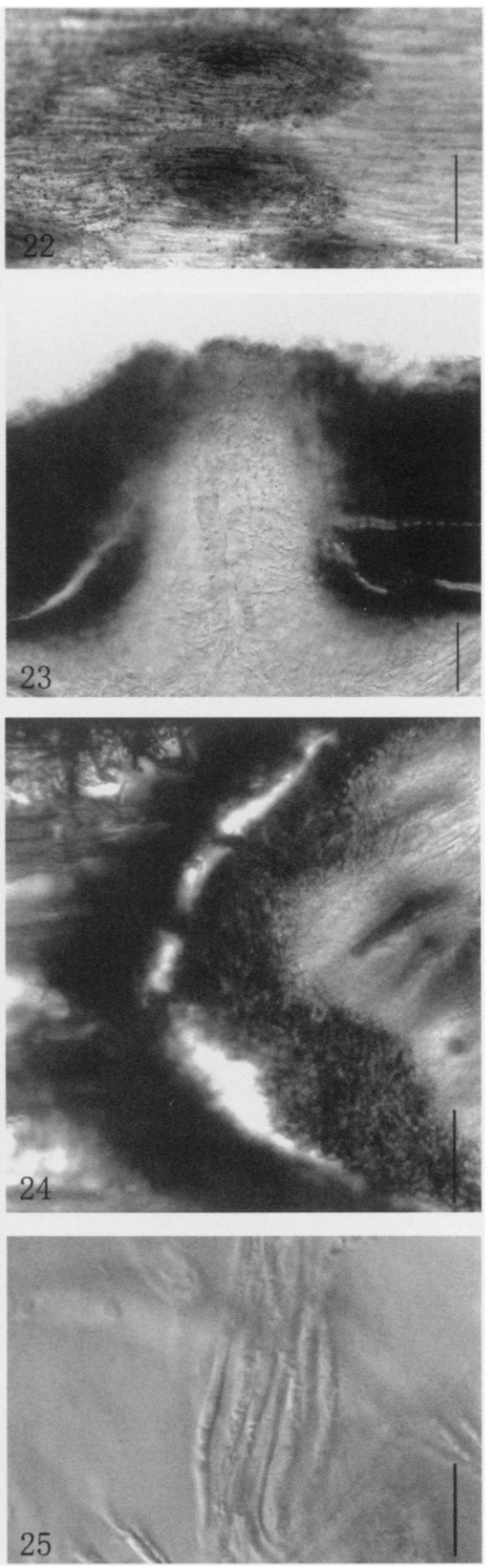

FIGS. 21-31. Interference contrast micrographs of Dyrithium lividum (from lectotype of Sphaeria livida). 21. Section of the ascoma. 22. Appearance of ascomata on host. 23. Section of ostiole (with periphyses). 24. Section of the peridium. 25. Paraphyses. 26-28. Asci (bitunicate). 29-31. Ascospores. Scale bars: $21=80 \mu \mathrm{m}, 22=600 \mu \mathrm{m}, 23=40 \mu \mathrm{m}, 24-25=20$ $\mu \mathrm{m}, 26-28=10 \mu \mathrm{m}, 29-31=7 \mu \mathrm{m}$.

(Figs. 21-22). Peridium up to $30 \mu \mathrm{m}$ thick, dark brown, comprising several layers of compressed cells (FIGs. 23-24). Paraphyses up to $3.5 \mu \mathrm{m}$ diam, filamentous, flexuose, numerous, embedded in a gelatinous matrix (FIG. 25). Asci 95-120 × 10-15 $\mu \mathrm{m}(\bar{x}$ $=107 \times 12.7 \mu \mathrm{m}, \mathrm{n}=20$ ), 8-spored, long cylindrical, bitunicate, pedicellate, apically rounded (FIGs. 2628). Ascospores $13-20 \times 7-10 \mu \mathrm{m}(\bar{x}=15 \times 8.7 \mu \mathrm{m}$, $\mathbf{n}=20)$, overlapping uniseriate, ellipsoidal, dull brown, with 3-5 transverse septa and one to several longitudinal septa, granular (FIGs. 29-31).

Material examined. Sweden, Småland. No date. Herb. Musei. Botanici Upasaliensis, UPS (F-05092) 59653.

Note: There were three specimens in UPS in Herbarium Fries Botanici Upsaliensis. The best specimen has been designated as lectotype. O. E. Eriksson examined this material in 1985 and labelled it as Thyr- 
idium lividum (Pers. Fr.) Sacc. The other two Sphaeria livida are isotypes.

Phylogenetic analyses. The alignment of the dataset consists of $900 \mathrm{bp}$, of which 189 were parsimony informative. Unweighted parsimony analyses and treating gaps as missing data resulted in three trees on one island. Tree length was 636 steps, $\mathrm{CI}=0.654, \mathrm{RI}$ $=0.695, \mathrm{RC}=0.455$ and $\mathrm{HI}=0.346$. Unweighted parsimony analyses (transition-transversion ratio of 1.5:1) of the same dataset resulted in one most-parsimonious tree of 765 steps, $\mathrm{CI}=0.654, \mathrm{RI}=0.700$, $\mathrm{RC}=0.457$ and $\mathrm{HI}=0.346$. Weighted parsimony analyses yielded trees with better resolution that were more strongly supported by bootstrap values than trees generated from unweighted parsimony analyses. The single parsimonious tree obtained by treating gaps as missing data and with a transition-transversion ratio of 1.5:1 is shown in FIG. 32. Maximum-likelihood (ML) analyses under the HKY model, with an estimated shape parameter of 0.2 and an estimated transition-transversion ratio of 1.7 , yielded a single tree of log-likelihood of 4345.69818. The topology of the ML tree is identical in that of FIG. 32 (results not shown). The phylogram generated under the neighbor-joining method was similar to FIG. 32 with a tree length of 644 steps, $\mathrm{CI}=0.646, \mathrm{RI}=0.684, \mathrm{RC}=$ $0.442 \mathrm{HI}=0.352$ and $-\log$ likelihood of 4646.14791 (FIG. 33).

Clade A (Fig. 32) supports the monophyly of all amphisphaeriaceaous genera producing Pestalotiopsis-like anamorphs and is supported by a high bootstrap confidence (99\%). Dyrithiopsis lakefuxianensis appear to be closely related to the genus Bartalinia Tassi and forms a sister group to the genus Truncatella Stey. These relationships also are supported by high bootstrap values.

\section{DISCUSSION}

Morphological studies coupled with phylogenetic analyses of rDNA sequences reported here provide additional insights regarding the systematic placement of the new genus Dyrithiopsis. On morphological grounds, Dyrithiopsis has close affinities to the genus Dyrithium, which currently is accommodated in the family Amphisphaeriaceae (Barr 1994). However, considerable taxonomic confusion surrounds the genus Dyrithium (Kang et al 1999a). The generic name Dyrithium, based on D. lividum, was introduced for Sphaeria livida by Barr (1994). Kang et al (1999a) examined a collection of Sphaeria livida, which was cited as having unitunicate asci by Barr (1994), and found that the asci were distinctly bitunicate (FIGS. 21-31, Kang et al 1999a). We requested Fries type material of Sphaeria livida to resolve this confusion.
The material, despite its age, is in reasonable condition, and ascomata contain numerous asci and ascospores. Although we could find no evidence that the asci were fissitunicate, it was clear that they were bitunicate (FIGS. 26-28) and reminiscent of genera such as Verruculina (Kohlm.) Kohlm. \& Volkm.Kohlm. (Hyde et al 2000). There was no J+ subapical ascal ring. Because of the ascal characters that are more typical of the loculoascomycetes, we are convinced that Dyrithium is not amphisphaeriaceous. The loculoascomycetous nature of the taxon also was evident in the pseudoparaphyses, which were long and straight between the asci, anastomosed above the asci, did not taper and were embedded in a gelatinous matrix. This is typical of bitunicate genera, such as Massarina Sacc., as compared to the sparse tapering paraphyses in the Amphisphaeriaceae (Poonyth et al 2000).

Similar confusion surrounds genera such as Roussella Sacc. and Saccardoella Speg. (Hyde et al 1996a) because, although the asci in these genera are bitunicate, they do not show fissitunicate dehiscence. We therefore describe a new genus Dyrithiopsis to accommodate our new taxon, which clearly is amphisphaeriaceous, based on its ascal characters. Characters pertaining to the Amphisphaeriaceae and related families already have been elaborated (Hyde 1996, Hyde et al 1996b, Kang et al 1999b).

The outcome of molecular analyses based on the large subunit rDNA sequences provide further evidence that Dyrithiopsis is phylogenetically related to other members of the family Amphisphaeriaceae (FIG. 32). In recent studies, it has been shown that ascomycetous genera producing Pestalotiopsis-like anamorphs as well as coelomycetous genera, such as Bartalinia, Discosia Libert, Pestalotiopsis Stey., Monochaetia (Sacc.) Allesh., Seimatosporium Corda, Seiridium Nees: Fries and Truncatella, are members of the family Amphisphaeriaceae (Kang et al 1998; 1999b; Jeewon et al 2002, 2003a, b). Based on morphological and molecular data, the taxonomic concept of this family has been revised to accommodate genera that produce Pestalotiopsis-like anamorphs (Kang et al 1998, 1999a, b). Results from our molecular study indicate that Dyrithiopsis is strictly amphisphaeriaceaous because it is nested between Discostroma Clements and Lepteutypa Petrak, which are members of the Amphisphaeriaceae sensu stricto (Barr 1994, Hawksworth et al 1995, Kang et al 1998, 1999b). In addition, it possesses unitunicate asci with a $\mathrm{J}+$ subapical ring and a Pestalotiopsis-like anamorph, characteristic of other members of this family.

The new genus Dyrithiopsis produced a coelomycetous anamorph with morphological affinities to Pestalotiopsis, Monochaetia and Seimatosporium. It has 
Discosia sp.

00 Discostroma tosta

67

Seimatosporium vacinii

${ }_{100}^{99}\left[\begin{array}{l}\text { Bartalinia robillardoides } \\ \text { Dyrithiopsis lakefuxianen }\end{array}\right.$

$*$

L Dyrithiopsis lakefuxianensis

A

99

75

75

Lepteutypa cupressi

$$
\text { - Truncatella angustata }
$$

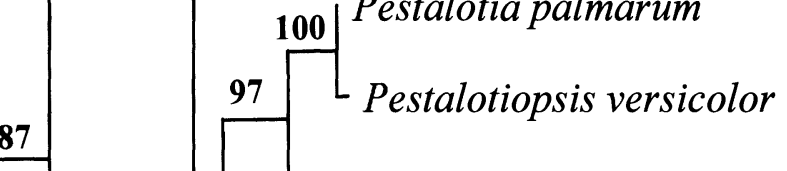

5onochaetia monochaeta

\section{Amphisphaeria umbrina}

100

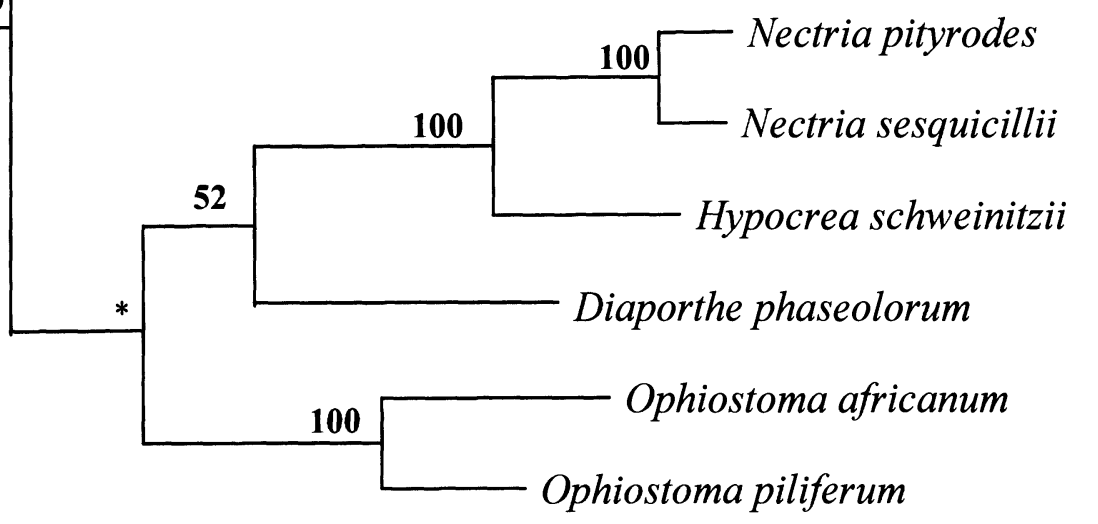

Dothidea sambuci

\section{0 steps}

Fig. 32. Phylogram depicting the relationships of Dyrithiopsis lakefuxianensis with respect to others members of the Amphisphaeriaceae. Tree was generated by a weighted parsimony analysis (transition transversion ratio of 1.5:1) from partial LSU sequences of the rDNA gene. Dothidea sambuci was the designated outgroup. Bootstrap values (1000 replicates) are indicated on nodes. * Represents those clades that collapsed in the bootstrap analysis. 


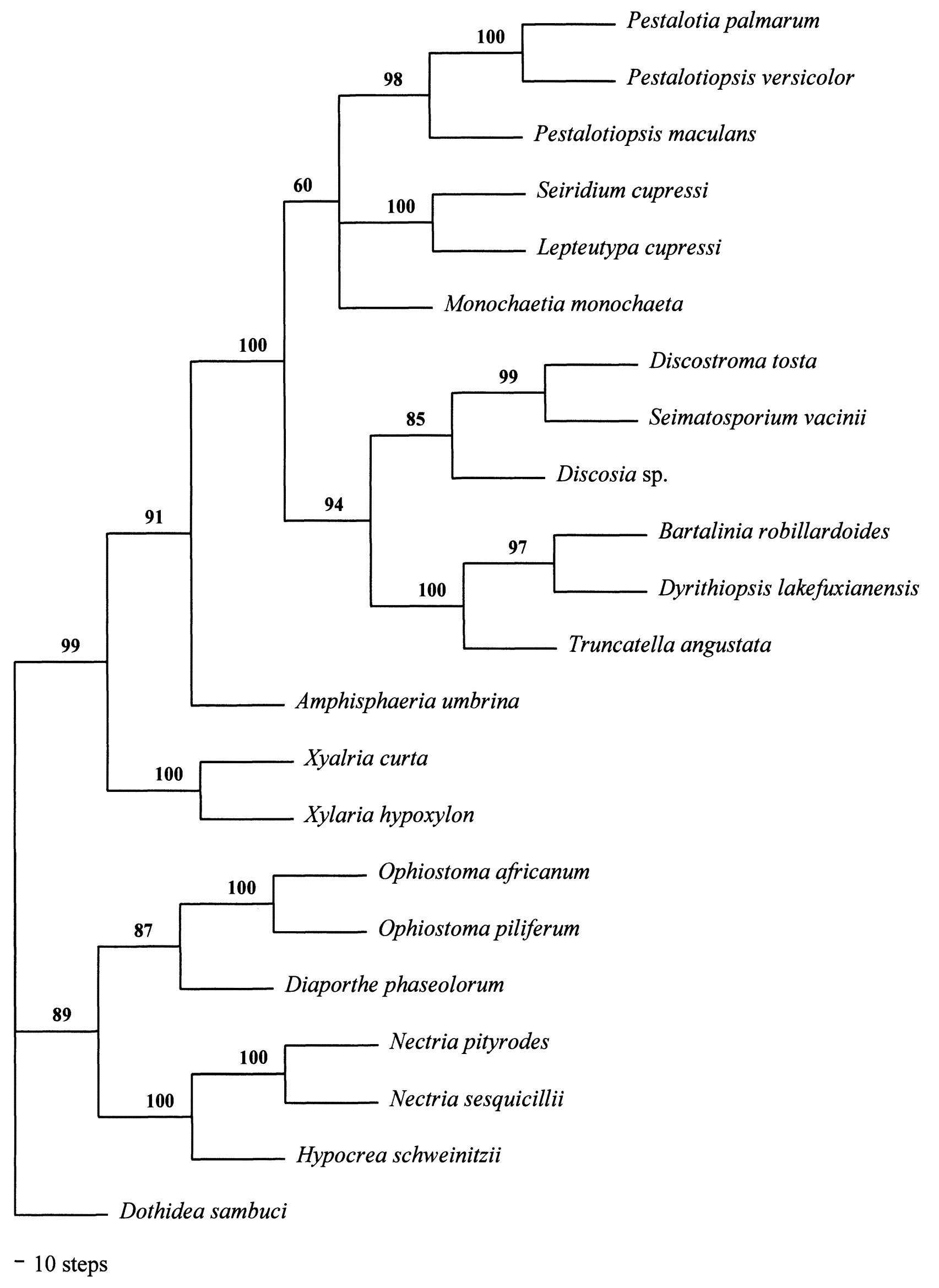

FIG. 33. Relationships among Dyrithiopsis lakefuxianensis and related taxa based on the neighbor-joining method. Phylogram is rooted with Dothidea sambuci and bootstrap frequencies are showed above the internodes. 
four euseptate fusoid, brown conidia, which are constricted slightly at the septum, similar to those species in Bartalinia, Pestalotiopsis, Monochaetia, Seimatosporium and Truncatella. This anamorph, however, is morphologically distinguishable from Monochaetia and Pestalotiopsis and Seiridium, with respect to the appendages and conidial shape. Conidia are fusiform elliptical and characterized by three pigmented (honey brown) median cells that are slightly constricted. End cells are hyaline, bear a single and short apical and basal appendage that are unbranched and usually curved and separated by a septum from the end cells. This anamorph also differs morphologically from Bartalinia and Truncatella (its closest relatives in the tree). Bartalinia is characterized by median cells that are almost hyaline or pale brown with apical appendages arising from a particular locus above the apical cell (unlike Monochaetiopsis, which is separated by a septum). Truncatella, however, possesses mostly two median cells with highly branched apical appendages. Further details regarding the morphological characters and phylogenetic relationships pertaining to Bartaliniam, Discosia, Pestalotiopsis, Monochaetia, Seimatosporium, Seiridium and Truncatella have been discussed by Jeewon et al (2002, 2003b). A new coelomycetous taxon, Monochaetiopsis lakefuxianensis therefore was erected to describe this fungus.

\section{ACKNOWLEDGMENTS}

This study was financially supported by the National Natural Science Foundation of China (NSFC 3026002, 30230020). We would like to thank UPS for kindly providing material for examination. Helen Leung and Heidi Kong are thanked for technical assistance.

\section{LITERATURE CITED}

Barr ME. 1994. Notes on the Amphisphaeriaceae and related families. Mycotaxon 51:191-224.

Cai L, Tsui CKM, Zhang K, Hyde KD. 2002. Aquatic fungi from Lake Fuxian, Yunnan, China. Fungal Diversity 9: 57-70.

Choi YW, Hyde KD, Ho WH. 1999. Single spore isolation of fungi. Fungal Diversity 3:29-38.

Doyle JJ, Doyle JL. 1987. A rapid DNA isolation procedure for small quantities of fresh leaf tissues. Phytochem Bull 19:11-15.
Gilbert DG. 1996. SeqPup, biosequence editor and analysis software for molecular biology Bionet. Software.

Goh TK. 1999. Single spore isolation using a hand-made glass needle. Fungal Diversity 2:47-63.

Hawksworth DL, Kirk PM, Sutton BC, Pegler DN. 1995. Ainsworth \& Bisby's dictionary of the fungi. 8th ed. Wallingford, UK: CAB International.

Hyde KD. 1996. Fungi from palms. XXIX. Arecophila gen. nov. Amphisphaeriaceae, Ascomycota, with five new species and two new combinations. Nova Hedwigia 63: 81-100.

— Eriksson OE, Yue JZ. 1996a. Roussoella, a genus of uncertain relationships with a Cytoplea anamorph. Mycol Res 100:1522-1528.

—, Kang JC, Kong RYC. 1996b. Fungi from palms. XXX. Notes on Amphisphaeria species described from palms and a description of A. umbrina. Nova Hedwigia 63:101-108.

— Sarma VV, Jones EBG. 2000. Morphology and taxonomy of higher marine fungi. In: Hyde $\mathrm{KD}$, Pointing SB, eds. Marine Mycology - a practical approach. Hong Kong: Fungal Diversity Press. p 172-204.

Kang JC, Kong RYC, Hyde KD. 1998. Studies on the Amphisphaeriales I. Amphisphaeriaceae (sensu stricto) and its phylogenetic relationships inferred from 5.8S rDNA and ITS sequences. Fungal Diversity 1:147-157.

— Hyde KD, Kong RYC. 1999a. Studies on Amphisphaeriales: the genera excluded from the Amphisphaeriaceae, Cainiaceae and Clypeosphaeriaceae. Fungal Diversity 2:135-151.

$\longrightarrow,-1$, 1999b. Studies on Amphisphaeriales: The Amphisphaeriaceae (sensu stricto). Mycol Res 103:53-64.

Jeewon R, Liew ECY, Hyde KD. 2002. Phylogenetic relationships of Pestalotiopsis and allied genera inferred from ribosomal DNA sequences and morphological characters. Mol Phylogenet Evol 25:378-392.

- - Simpson JA, Hodgkiss IJ, Hyde KD. 2003. Phylogenetic significance of morphological characters in the taxonomy of Pestalotiopsis species. Mol Phylogenet Evol 27:372-383.

Jeewon R, Liew ECY, Hyde KD. 2003b. Molecular systematics of the Amphisphaeriaceae based on cladistic analyses of partial LSU rDNA gene sequences. Mycological Research (In press).

Poonyth AD, Hyde KD, Aptroot A, Peerally A. 2000. Mauritiana rhizophorae gen. et sp. nov. (Ascomycetes Requienellaceae), with a list of terrestrial saprobic mangrove fungi. Fungal Diversity 4:101-116.

Swofford DL. 2002. PAUP*: phylogenetic analysis using parsimony and other methods. Version 4.0b8. Sunderland, Massachusetts U.S.A. Sinauer Associates. 